\title{
DESKRIPSI HASIL BELAJAR MATEMATIKA SISWA MENGGUNAKAN KONSEP STIFIN LEARNING PADA JENJANG SMP DAN SMA DI KOTA MAKASSAR
}

\author{
Lestari Ratu Ayu \\ Pendidikan Matematika, Fakultas Keguruan Dan Ilmu Pendidikan \\ Universitas Pancasakti Makassar \\ l.ratuayu@gmail.com
}

\begin{abstract}
ABSTRAK
Penelitian ini bertujuan untuk melihat nilai hasil belajar siswa sesuai dgn KKM menggunakan konsep STIFIn Learning pada jenjang SMP dan SMA di Kota Makassar. Penelitian ini merupakan penelitian Narasi melalui desain penelitian pendekatan kualitatif. populasi penelitian ini terdiri dari 9 orang dari masing-masing personality genetik yang tersebar di berbagai sekolah jenjang SMP dan SMA di Kota Makassar. Instrument dan Teknik yang digunakan adalah wawancara melalui fortofolio QnA melalui google form. Data yang diperoleh kemudian dibuat narasi dan dianalisa. Hasil Penelitian menunjukkan hasil terbaik, dimana peserta didik dapat dengan mudah dan nyaman melakukan proses belajar tetapi dengan hasil terbaik dalam hal ini sesuai KKM.
\end{abstract}

Kata Kunci: Stifin Learning, Hasil Pembelajaran

\begin{abstract}
This study aims to see the value of student teaching results in accordance with the KKM using the STIFIn Learning concept at the junior and senior high school levels in Makassar City.This research is a narrative research through a qualitative approach research design. The population of this study consisted of 9 people with each genetic personality spread across various junior and senior high schools in Makassar City. The instruments and techniques used were interviews through the QnA portfolio via google form. The data obtained were then made narrative and analyzed.The results showed the best results, where students could easily and comfortably carry out the learning process but with the best results in this case according to the KKM.
\end{abstract}

Keyword: Stifin Learning, Learning Outcomes

\section{A. PENDAHULUAN}

Setiap tahun dalam dunia Pendidikan mengalami kendala untuk meningkatkan prestasi belajar peserta didik, dimana banyak anak merasa kesulitan dalam belajar, boleh jadi ada anak yang cara belajarnya sudah sesuai dengan sistem Pendidikan yang diterapkan di sekolah, namun ada juga anak yang cara belajarnya diluar dari konsep kurikulum seperti: harus menghafal, belajar didalam kelas, ruang tertutup dengan penekanan yang ekstra terhadap peserta didik sementara anak-anak dipaksa untuk memperoleh hasil belajar yang maksimal dengan cara yang menekan tanpa memperhatikan minat dan bakat siswa. 
Padahal Pendidikan memegang peranan penting dalam mempersiapkan sumber daya manusia yang berkualitas yang diharapkan mampu berkompetisi dalam perkembanagan ilmu pengetahuan dan teknologi, sehingga Pendidikan harus dilaksanakan dengan sebaik-baiknya untuk memperoleh prestasi belajar yang maksimal.

Menurut Agung (2017: 23) Sekolah adalah tempat lahirkannya para pelaku peradaban dunia, dan para pendidik di dalamnya adalah mereka yang berperan aktif membentuk para penoreh sejarah tersebut.

Bagi anak-anak peserta didik yang duduk di bangku sekolah maupun kuliah, tentu terdapat pelajaran matematika yang nilainya harus bagus atau diatas rata-rata minimum sebagai syarat kenaikan kelas atau tingkat ke semester selanjutnya. Namun, apakah kita cukup mengandalkan cara dan ilmu yang sama ketika masuk kerja, tentu tidak. Kita harus memiliki ilmu dan keterampilan baru untuk naik ke jenjang yang lebih tinggi. Artinya, kita sebagai manusia akan terus bertumbuh. Kita tidak pernah bisa lepas dari sebuah proses bernama "Belajar".

Masalahnya, tidak semua orang dapat belajar dengan mudah. Hal ini yang membuat peneliti berkecimpu dalam dunia pengembangan minat dan bakat untuk mengetahui sekaligus menunjukkan betapa pentingnya mengetahui cara belajar masing- masing orang melalui konsep STIFIn.

Konsep STIFIn diperkenalkan oleh Farid Poniman dengan mengkompilasi dari berbagai teori psikologi, neuro science, dan SDM. Prinsip besarnya mengacu kepada konsep kecerdasan tunggal dari C.G Jung. Tes yang dilakukan dengan cara men-scan kesepuluh ujung jari (mengambil waktu tidak lebih dari satu menit). Sidik jari yang membawa informasi tentang komposisi susunan syaraf tersebut kemudian dianalisa dan dihubungkan dengan belahan otak tertentu yang dominan berperan sebagai sistem operasi dan sekaligus menjadi jenis kecerdasan. Bahkan dari susunan syaraf tersebut masih dapat diprediksi letak dominasi mesin kecerdasan yang ada di lapisan otak berwarna putih atau di lapisan otak berwarna abu-abu. Poniman (2013 :15)

Apapun pelajarannya, apapun ilmunya, apapun keterampilannya dengan cara belajar yang pas kita bisa belajar dengan mudah dan nyaman. Hasil belajarpun, bisa dicapai dengan maksimal. Badaruzzaman, (2014 : 71)

Everybody is a genius. but if you judge a fish by its ability to climb a tree will live its whole life believing that it is stupid" (Albert Einstein dalam buku I know You, 2017)

Artinya : "Setiap orang cerdas. tetapi jika kamu menilai seekor ikan mampu untuk memanjat sebuah pohon maka dalam hidupnya ia akan merasa bodoh."

Konsep stifin learning merupakan cara yang unik dan sangat individual yang dapat kita gunakan dalam belajar. karena sifatnya unik maka antara siswa yang satu dengan siswa lainnya mempunyai pendekatan yang berbeda dalam belajar. (Agung, 2017: 27).

Konsep STIFIn digunakan sebagai instrument yang memaparkan praktik dan penerapan pengembangan diri. konsep ini cukup bisa mewakili kebutuhan dalam memetakan potensi terbaik seseorang. (Asbari, $2015:$ 1)

Adapun STIFIn Learning adalah sebuah konsep belajar yang bertujuan menjadikan aktivitas belajar menjadi lebih mudah dan nyaman, sekaligus memberikan hasil belajar yang lebih maksimal sesuai dengan bakat alami anak. (Badaruzzaman, $2014: 71$ )

Pada pembelajaran matematika di sekolah merupakan salah satu komponen Pendidikan yang tidak hanya mengembangan kemampuan dan keterampilan menerapkan matematika melainkan mengembangankan kemampuan memecahkan masalah.(Ahmad, 2016) 
Inti dari instrumen konsep stifin adalah anda dapat mengetahui potensi diri, baik secara fenotip maupun genotif. dimana Fenotip adalah potensi yang sudah dipengaruhi faktor lingkungan selama ini, baik dari aspek keluarga, Pendidikan atau masyarakat, sedangkan potensi genotif adalah potensi yang bersigat gen atau bawaan sejak lahir tidak dapat berubah meski bukan dari turunan dari orang tua (keturunan), given yang Mahakuasa sehingga kecenderungannya tidak berubah. inilah yang membuaut peneliti menggunakan pengukuran dari instrument konsep stifin.

Adapun dalam deskripsi instrument konsep stifin diperlukan data peserta didik yang telah melakukan tes sidik jari sebelumnya sehingga nantinya akan menggambarkan siklus pembelajaran yang menunjukkan nilai matematika siswa sesuai dengan KKM.

Mengacu pada kondisi diatas maka penelitian dibatasi tentang deskripsi konsep STIFIn mampu menunjukkan hasil belajar sesuai dengan KKM siswa pada pembelajaran Matematika .

Maka dari itu penulis memformulakan pembelajaran matematika menggunakan konsep STIFIn, untuk memudahkan peneliti dalam menggambarkan siklus konsep stifin learning dan tentu membantu siswa memperoleh cara yang paling efektif dalam memahami pemebelajaran matematika lewat karakter pribadi atau mesin kecerdasan. sehingga nantinya akan terlihat bagaimana konsep stifin learning ini tetap menunjukkan hasil belajar siswa sesuai KKM.

Identifikasi Masalah

Berdasarkan uraian latar belakang, maka dapat diidentifikasikan beberapa masalah sebagai berikut :

1. Belum optimalnya hasil belajar siswa pada pelajaran matematika

2. Guru belum menguasai gambaran besar deskripsi Konsep STIFIn,

3. Terdapat siswa yang belum intens dalam mengaplikasikan konsep stifin learning. Pembatasan Masalah

Agar permasalahan yang diteliti tidak meluas, maka peneliti membatasi permasalahan sebagai berikut:

1. Populasi dan Sampel merupakan siswa(i) yang sudah tes STIFIn dari berbagai sekolah jenjang SMP DAN SMA di kota Makassar

2. Yang menjadi tolak ukur hasil belajar yaitu mengisi QnA berisi daftar hasil belajar (nilai) matematika kemudian oleh peneliti mendeskripsikan sesuai konsep STIFIn di sekolah SMP dan SMA Se-kota Makassar

3. Hasil belajar mengacu pada daftar nilai ulangan matematika terbaru semester genap tahun ajaran 2019-2020.

Rumusan Masalah

Berdasarkan ruang lingkup pembatasan masalah yang telah ditentukan, maka rumusan masalah yang diajukan peneliti dalam skripsi ini adalah "Bagaimana siklus stifin learning mampu menunjukkan nilai matematika siswa sesuai kkm (kriteria ketuntasan minimal) pada jenjang SMP dan SMA di Kota Makassar?"

Tujuan Penelitian

Untuk mengetahui siklus stifin learning mampu menunjukkan nilai matematika siswa sesuai kkm (kriteria ketuntasan minimal) pada jenjang SMP dan SMA di Kota Makassar.

\section{B. METODE}

1. Jenis dan Lokasi Penelitian

Sebelum penelitian dilakukan, kegiatan dimulai dengan konsultasi awal, dan observasi siswa dengan orang tua maupun guru matematika untuk mengetahui perkembangan siswa 
dalam pembelajaran matematika, tentu kepada mereka peserta didik yang telah melakukan tes stifin. Dari hasil observasi, siswa dan peneliti berdiskusi tentang permasalahan penelitian dan perencanaan tindakan.

Penelitian ini dilaksanakan pada siswa SMP dan SMA di Kota Makassar. Penelitian dilakukan mulai bulan Juni 2020 pada semester genap melalui data primer Question dan answer google form.

Hal ini didasarkan pada rumusan-rumusan yang muncul pada penelitian ini yang menuntut peneliti untuk melakukan berbagai aktifitas narasi dalam rangka memahami dan menjelaskan masalah-masalah yang menjadi fokus penelitian ini. Kemudian pengumpulan berbagai data dan informasi akan dilakukan melalui observasi, question and answer by google form online melalui link yang dibagikan oleh peneliti kepada para peserta didik yang dalam hal ini obyek penelitian, dokumentasi sumber-sumber data yang diperlukan yang merupakan hasil dari QnA.

Jenis penelitian yang digunakan adalah pendekatan kualitatif jenis Narasi, metode Penelitian ini merupakan cara ilmiah untuk mendapatkan data dengan tujuan dan kegunaan tertentu. cara ilmiah berarti kegiatan penelitian itu didasarkan pada ciri-ciri keilmuan, yaitu rasional, empiris dan sistematis. Rasional berarti kegiatan penelitian itu dilakukan dengan caracara yang masuk akal, sehingga terjangkau oleh penalaran manusia. Empiris berarti cara-cara yang dilakukan itu dapat diamati oleh indra manusia. Sistematis artinya proses yang dilalukan dalam penelitian ini menggunakan siklus tertentu yang bersifat logis (Sugiono, 2009)

Penelitian pendekatan kualitatif dengan metode narasi ini bertujuan memperoleh gambaran mengenai hasil belajar menunjukkan kesesuaian KKM dengan melihat flasback kegiatan peserta didik menggunakan siklus konsep STIFIn Learning pada siswa SMP dan SMA di Kota Makassar.

Dengan narasi melibatkan peneliti aktif dalam setiap aktifitas peniliaian sehingga memperoleh hasil maksimal. pada peserta didik mempunyai sikap percaya diri, mandiri dan nyaman serta menemukan cara yang paling efektif dan efisien dalam proses pembelajaran matematika karena bekerja sesuai kepribadian.

Penelitian ini menggunakan jenis penelitian Kualitatif yaitu data yang diperoleh dari peningkatan hasil belajar siswa SMP dan SMA di Kota Makassar, dalam bentuk informasi baik secara lisan by handphone maupun secara tulisan seperti data-data berupa penjelasan atau pernyataan yang tidak berbentuk angka akan tetapi merupakan gambaran hasil belajar siswa juga siklus peserta didik dalam mempelajari matematika menggunakan konsep stifin learning. Penelitian ini akan dilakukan pada siswa SMP dan SMA di Kota Makassar dengan pengambilan data berdasarkan penelitian tindakan. Penelitian ini dilakukan selama satu bulan yaitu bulan Juni- Juli 2020. Adapun pihak sekolah yang terlibat antara lain :

Tabel 1. Sekolah lokasi penelitian

\begin{tabular}{ccc}
\hline No. & Lokasi Penelitian & Personaliti Genetik \\
\hline 1 & SMP NEG. 06 MAKASSAR & Sensing Introvert \\
\hline 2 & SMA NEG. 14 MAKASSAR & Sensing Ekstrovert \\
\hline 3 & SMP UNISMUH MAKASSAR & Thinking Introvert \\
\hline 4 & SMP UNISMUH MAKASSAR & Thinking Ekstrovert \\
\hline 5 & SMP NEG. 01 MAKASSAR & Intuiting Introvert \\
\hline 6 & SMP NEG. 06 MAKASSAR & Intuiting Ekstrovert \\
\hline 7 & SMA NEG. 01 MAKASSAR & Feeling Introvert \\
\hline
\end{tabular}




\begin{tabular}{ccc}
\hline 8 & SMP NEG. 06 MAKASSAR & Feeling Ekstrovert \\
\hline 9 & SMA NEG. 29 MAKASSAR & Insting \\
\hline
\end{tabular}

2. Adapun variabel yang digunakan mencakup konsep learning yang mengacu pada literatur (workshop, penelitian terdahulu, buku-buku stifin learning), instrument fortofolio berbentuk Question and answer dengan objek peneliti.

3. Defenisi Istilah

STIFIn = Sensing, Thinking, Intuiting, Feeling, dan insting

MK = mesin kecerdasan (belahan otak dominan)

$\mathrm{PG}=$ personality genetic (genetic individu)

introvert $=$ kemudi dari dalam

ekstrovert $=$ kemudi dari luar

$S i=$ sensing introvert (memory Quotients)

$\mathrm{Se}=$ sensing ekstrovert (physical quotients)

Ti $=$ thinking Introvert (technical quotients)

Te $=$ thinking Ekstrovert (logical quotients)

Ii = intuiting introvert (creativity quotients)

Ie = intuiting ekstrovert (spatial quotients)

$\mathrm{Fi}=$ feeling introvert (emotional quotients)

$\mathrm{Fe}=$ feeling ekstovert (social quotients)

In = insting (altruis quotient)

4. Populasi penelitian ini terdapat pada Siswa SMP dan SMA di Kota Makassar yang telah tes STIFIn. Adapun jumlah Sampel Siswa sebanyak 9 orang terdiri dari 5 MK dan 9 PG. Objek penelitian ini adalah Hasil Belajar Siswa SMP dan SMA di Kota Makassar pada pembelajaran matematika menggunakan konsep STIFIn Learning.

Ciri Penelitian Kualitatif tidak dapat dipisahkan dari pengamatan berperan serta, namun peranan penelitilah yang menentukan segala skenarionya. penelitian ini yang menjadi instrument penelitiannya adalah penelitian itu sendiri. Karena dalam penelitian kualitatif peneliti bertindak sebagai intsrumen. Hal ini berarti peneliti merupakan perencana, pelaksana, pengumpul data dan pada akhirnya menjadi pelopor hasil penelitiannya, keberadaan peneliti sebagai instrument merupakan alat pengumpul data utama.

5. Instrumen merupakan alat yang digunakan untuk melakukan penelitian. sedangkan peneliti memiliki arti pemeriksaan, penyelidikan, kegiatan pengumpulan, pengolahan, analisis dan penyajian data secara sistematis dan objektif serta subjektif dengan tujuan memecahkan sesuatu persoalan. jadi semua alat (dalam bentuk wawancara, Observasi, instrument fortofolio Question and answer via google form online) juga penelitian pustaka yang bisa mendukung suatu penelitian. seluruh alat yang digunakan dalam penelitian tersebut merupakan instrument dalam penelitian ini.

6. Teknik Pengumpulan Data Untuk memperoleh data yag diperlukan dalam penulisan ini, maka metode yang digunakan dalam pengembalian data adalah : Penelitian Lapangan Dan Pustaka, data primer dengan cara observasi, wawancara dan fortofolio

7. Desain penelitian ini dilakukan dengan menggunakan desain penelitian studi kasus, dengan tujuan mendeskripsikan isu yang spesifik dan konseptual secara mendalam. lingkup desain penelitian studi kasus sangat terbatas hanya pada satu isu tentang deskripsi konsep STIFIn Learning menunjukkan hasil belajar sesuai KKM. 


\section{HASIL DAN PEMBAHASAN}

Kecerdasan Sensing Intovert didominasi oleh belahan otak limbik kiri dan lapisan kemudi kecerdasan dari tipe sensing introvert berada di lapisan abu-abu di bagian dalam limbik kiri itulah yang menjadi system operasi tipe "Se" kecerdasan tipe sensing introvert merujuk kepada kecerdasan indrawi. Tipe yang kecenderungannya berpijak pada yang nyata dan aktual. mengolah informasi berdasarkan panca indra. lebih berminat pada aplikasi praktis dan konkrit. mengandalkan pengalaman dan mampu menguraikan peristiwa secara urut.

Untuk memudahkan dalam mendskripsikan hasil belajar menggunakan konsep STIFIn Learning penulis membuat fortofolio ke dalam tabel pengamatan hasil wawancara "Question and Answer by google form online" berikut sajiannya:

Tabel 2. Question And Answer From Google Form

\begin{tabular}{ll}
\hline \multicolumn{1}{c}{ Nama Siswa } & \multicolumn{1}{c}{ Aril Hidayatullah } \\
\hline Mesin Kecerdasan & Sensing Introvert \\
\hline Kelas & Bi 1 \\
\hline Guru Mapel Matematika & Pak Abdi \\
\hline Nama Sekolah & Smpn 06 Makassar \\
\hline Tahap Persiapan (Internal) & Fisik \\
\hline External (Pendukung) & Fasilitas \\
\hline Eksternal (Lingkungan) & Imbalan \\
\hline Tahap Pelaksanaan & Mencontoh \\
\hline Kalibrasi Belajar & Berkeringat \\
\hline Penyakit Belajar & Kompensasi \\
\hline Antisipasi Penyakit Belajar & Fasilitas Dan Imbalan \\
\hline Mengatasi Penyakit Belajar & Ciptakan Kondisi Kondusif \\
\hline Nilai Matematika & 93 \\
\hline
\end{tabular}

Berdasarkan tabel diatas menunjukkan kesesuaian antara cara belajar anak dengan konsep stifin learning. Pada siswa kelas VIII SMP Negeri 06 Makassar bernama Aril Hidayatullah telah melakukan proses pembelajaran berstandar stifin selama stay at home dikarenakan darurat covid -19, dengan nilai akhir matematika sebesar 93 termuat dalam tabel 4.2, ia peroleh dari ulangan online by zoom yang diberikan oleh guru mata pelajaran di sekolahnya.

Persiapan internal adalah persiapan diri seseorang sebelum memulai aktivitas belajar. Persiapan yang dilakukan pembelajar (siswa) belum melibatkan sesuatu diluar diri peserta didik sebab sesuatu itu harus dimulai dan diawali dari dalam diri sendiri. adapun persiapan yang ia siapkan setiap baru memulai belajar adalah fisik, "pemanasan biar melumas otot setelah lentur tubuhku ku lebih fresh tuk menerima pelajaran" nah istilah ini 
bisa diistilahkan dengan melakukan peregangan tubuh (streching). Orang sensing dominan kinestetik, maka gerakan-gerakan tersebut akan merangsang otak lebih terbuka untuk mendapat informasi.

Sementara persiapan eksternal Aril Hidayatullah adalah fasilitas dan imbalan yaitu rentetan persiapan meliputi faktor pendukung dan lingkungan yang harus dikondisikan sebelum seseorang memulai aktivitas belajar. Jadi, selain faktor pribadi ada juga faktor lain bisa mencakup orang lain, situasi, tapi yang terpenting faktor orang tua sebagai parenting. "aku merasa kesulitan saat belajar jika kondusi kelas rebut dan tidak ada tantangan, jelas sekali masa pandemic buat belajar online bikin ogah belajar" Oleh karena itu persiapan eksternal ini dilakukan untuk mendukung proses belajar peserta didik dalam hal ini. sebagai orang tua juga bisa mempersiapkan diri untuk mempersiapkan faktor pendukung membimbing dirumah.

Maka seperti yang tertera pada tabel 2 diatas faktor pendukungnya adalah Fasilitas. orang dengan mesin kecerdasan sensing ini ingin serbacepat dan semua tersedia. jika perlu sesuatu ia ingin semuanya serba ada- lengkap. adapun yang Aril butuhkan dan tersedia adalah meja belajar dengan kondisi ruangan yang nyaman, santai, dan sejuk. persiapan seperti alat tulis juga tidak lupa untuk disediakan dan tersusun rapi. sehingga saat butuh mudah untuk menggunakannya. "selain alat tulis dan perlengkapan belajar sya juga butuh jaringan internet yang on terus"

Nah, saat semua fasilitas persiapan sudah tersedia lengkap sensing akan merasa nyaman untuk belajar. Jika terdapat fasilitas yang belum lengkap maka orangtua dapat mensiasati dengan kebutuhan yang nyaris sama, tidak perlu mahal yang jelas ada. Sehingga dia merasa kebutuhannya difasilitasi oleh orang tua. Sebab kalau tidak, semangat belajarnya sudah dipastikan turun beberapa persen.

Kesimpulannya, jika ingin hasil maksimal, fasilitas bagi orang sensing adalah keharusan.

Adapun lingkungan sensing adalah imbalan yaitu sesuatu yang konkrit. Dia senang belajar jika ada hadiah. Imbalan dimaksud sebagai iming-iming jika kemudinya ekstrovert maka ia paling senang dengan hadiah, "saya minta diberikan duit tambah buat bli Hp" kalimat ini paling sering dikumandangkan dan harus diiayakan Saat ia mencapai itu maka harus diberikan.

Selanjutnya cara belajarnya yaitu mencontoh, Tukang tiru, ATM (ambil, tiru, modifikasi), rajin latihan, do it, direkam. "saya sering membaca tapi masih belum paham tapi saat saya melakukan dan membawa ke contoh nyata soal-soal berupa coretan guru dari pembelajaran cerita pendek baru dapat dituangkan ke buku" jadi memaksimalkan potensi terbaiknya dengan memori besar dan kehebatan di mylinnya. Oleh karena itu, Ariel dapat meniru dengan apa yang ditangkap oleh pancainderanya.

Sedetail mungkin ia menangkap momentum dalam belajar, lalu menyimpan di dalam memorinya yang mempunyai daya ingat yang luar biasa.

Banyak melakukan latihan secara konsisten setiap hari, memecahkan soal secara berulang-ulang memacu mylinnya untuk terbiasa dan akrab dengan rumusan soal matematika ketika mylinnya terbentuk dengan mudah ia menangkap benang merah dari latihan soal sehingga saat soal ulangan mudah diingat, kata kuncinya dibaca, urut, hafal dan lakukan secara konsisten diulang terus menerus sampai bisa.

Bagi sensing Introvert akan lebih bagus langsung memperbanyak mengulang soalsoal matematika, sebab ingatan akan menjadi lebih baik jika diterapkan sebagai 
pengalaman. peluangnya terekam dari seringnya ia bertempur dengan soal-soal latihan.

Setelah menerapkan cara belajar mesin kecerdasan sensing introvert, sekarang kita sadar, mengapa ada anak yang nyaman dalam belajar dengan hasil berprestasi, tanda suatu kesyukuran ketika pas dengan cara belajar siswa. Jadi, secara sadar kita mulai menerapkan pelaksanaan cara belajar seuai dengan potensi terbaiknya. Analoginya "jika sesuatu ditempatkan sesuai makanatnya pasti hasilnya akan memuaskan", ketika ada kendala mudah untuk teratasi.

Menjadi sebuah pertanyaan baru, apakah "stamina" siswa terus terjaga sepanjang proses belajar? tentu tidak, sangat manusiawi jika mendapati siswa mulai kendur dalam belajar, boleh jadi ada hal yang kurang pas diterapkan, akan tetap konsep stifin learning memberikan sebuah cara agar siswa tetap "on" terus dalam belajar, bahkan dalam jangka waktu yang relative lama.

Adapun dalam mengupayakan belajar yang terus membaik perlu diterapkan system kalibrasi. iya, kalibrasi adalah jawaban agar siswa terus "on" dalam berproses. kalibrasi yang membuat refresh setelah jenuh. Tentu bagi setiap mesin kecerdasan dan personality genetic memiliki perbedaan satu sama lain. kalibrasi yang "gue banget" sesuai dengan bakat alaminya.

Adapun kalibrasi yang dilakukan oleh si sensing intovert adalah berkeringat, pembelajaran disimpan dulu dan melakukan kegiatan sparring berupa aerobic, dengan olahraga sejenak sehingga mengeluarkan keringat setidaknya mampu me-recharge stamina ototnya untuk belejar lebih efektif kembali setidaknya dalam proses tersebut ia mampu tuk mengembalikan suasana belajar yang menyenangkan.

Pada Tabel 2 menunjukkan siklus terakhir dalam siklus stifin learning yaitu tahap evaluasi. tahap ini diperlukan untuk mengukur sejauh mana kemajuan aktivitas belajar. sebelumnya pemilik kecerdasan personality genetik telah melalui dua siklus dengan maksimal dan penuh komitmen agar peluang menperoleh hasil yang maksimal juga lebih besar.

Dari tahap evaluasi terdapat hal yang perlu diperbaiki atau ditingkatkan lagi. selain itu juga terdapat penyakit belajar, antisipasi dan cara mengatasi penyakit belajar. artinya setiap kepribasian juga memiliki kecenderungan "mengidap" penyakit belajar tertentu.

Pada personality sensing yang jadi penyakit belajarnya adalah Manja saat diajak tuk belajar karena selalu ingin dilihat tuk diajar, kedewasaan lambat sebab menginginkan pendampingan lebih dari guru atau pengajarnya, suara melengking maksudnya cemprengnya merupakan suara yang terselubung muncul tiba-tiba saat dalam proses belajarnya tak sesuai ekspektasi, susah Mulai karena perlu imbalan yang lebih, Boros saat menerima imbalan sebagai penikmat, Cepat merasa tersudut saat kesulitan memecahkan soal mendapati diri stagnan.

Kesimpulannya bagi sensing introvert penyakit belajarnya adalah kompensasi, yaitu memiliki rasa mengompensasi hasil dari pembelajaran dengan cara yang lain. dia bilang "tidak baca buku juga tidak masalah, kan bisa tanya teman" mencari alasan untuk tidak belajar.

Cara mengantisipasi jika penyakit belajar datang adalah ciptakan kondisi positif dengan memaksimalkan tahap persiapan belajarnya dari segi fisik, fasilitas, dan imbalan. libatkan ia selalu dalam kondisi fisik yang prima untuk memulai aktivitas belajar. dengan persiapan fisik yang prima, otak orang sensing lebih siap dalam menerima proses pembelajaran. Siapkan juga yang berhubungan dengan fasilitas-fasilitas pendukung proses 
pembelajaran. yang penting, selalu ciptakan lingkungan yang jelas dengan imbalan yang konkrit dan konsisten agar orang sensing tidak mengkambing hitamkan diri sendiri dan tidak mencari alasan dengan hal-hal yang berhubungan dengan penyakit belajarnya, yaitu kompensasi.

Tingkatkan kondisi positif dengan kenali kondisi internal dan eksternal diri. jauhkan anak (siswa) dari munculnya pemicu penyakit belajar, kemudian sebanyak mungkin libatkan diri pada kondisi yang menjauhkan dari muculnya pemicu penyakit belajar. Minimalkan kondisi negatif dengan menghindarkan hal-hal yang memicu penyakit belaajar.

Terakhir cara mengatasi penyakit belajar adalah menerima penyakit yang ada, maksudnya ketika penyakit datang, terima dengan jujur, terutama diri sendiri. hindari sifat defensif karena hal tersebut hanya akan semakin mempersulit keadaan hadapi penyakit dengan melakukan aksi-aks yang berseberangan dengan penyakit yang datang, tentu dengan bimbingan mentor atau guru bimbingan terbaik sehingga proses sehingga proses yang jelas arahnya dan terencana. Seyogyanga penyakit kompensasi dengan aksi menekuni proses belajar yang diniatkan untuk ditinggalkan.

Dari narasi diatas kita dapat melihat bahwa nilai peserta didik dengan kepribadian sensing introvert mampu mencapai nilai standar yang ditetapkan oleh satuan Pendidikan yaitu 70 dengan total nilai akhir diperoleh 93, sehingga dapat dikatakan ia telah berhasil menerapkan siklus konsep stifin untuk menunjukkan eksistensinya dalam ruang lingkup Pendidikan.

\section{PENUTUP}

1. Kesimpulan

Adapun siklus belajar dalam menggunakan konsep stifin adalah sebagai berikut:

a. Sensing, diawali dengan pemanasan fisik, kemudian mencontoh maupun meniru adalah intinya dan dievaluasi dengan mengatasi penyakit belajarnya yaitu kompensasi dan inferioritas. Dari siklus tersebut kita dapat melihat bahwa nilai peserta didik dengan kepribadian sensing introvert mampu mencapai nilai standar yang ditetapkan oleh satuan Pendidikan yaitu 70 dengan total nilai akhir diperoleh 93, Adapun bahwa nilai peserta didik dengan kepribadian sensing ekstrovert mampu mencapai nilai standar yang ditetapkan oleh satuan Pendidikan yaitu 70 dengan total nilai akhir diperoleh 82, sehingga dapat dikatakan ia telah berhasil menerapkan siklus konsep stifin untuk menunjukkan eksistensinya dalam ruang lingkup Pendidikan.

b. Thinking, diawali dengan berpikir logis, fokus sesuai sasaran pembelajaran, kemudian menganalisa adalah inti cara belajarnya dan diakhiri evaluasi dengan mengatasi penyakit belajarnya yaitu fiksasi dan rasionalisasi. dengan demikian bahwa nilai peserta didik dengan kepribadian thinking introvert mampu mencapai nilai standar yang ditetapkan oleh satuan Pendidikan yaitu 70 dengan total nilai akhir diperoleh 95, adapun nilai peserta didik dengan kepribadian thinking ekstrovert mampu mencapai nilai standar yang ditetapkan oleh satuan Pendidikan yaitu 70 dengan total nilai akhir diperoleh 90, sehingga dapat dikatakan ia telah berhasil menerapkan siklus konsep stifin untuk menunjukkan eksistensinya dalam ruang lingkup Pendidikan.

c. Intuiting, diawali dengan membangun hasrat, kemudian mempolakan dan simulasi soal - soal latihan adalah intinya dan diakhiri evaluasi untuk mengatasi penyakit belajarnya yaitu proyeksi dan fantasi. dan dari narasi yang diperoleh maka nilai peserta didik dengan kepribadian intuiting introvert mampu mencapai nilai standar yang ditetapkan oleh satuan Pendidikan yaitu 70 dengan total nilai akhir diperoleh 83. Adapun nilai peserta didik dengan kepribadian intuiting ekstrovert mampu mencapai nilai standar yang ditetapkan oleh satuan Pendidikan yaitu 70 dengan total nilai akhir diperoleh 97, sehingga dapat dikatakan ia telah berhasil menerapkan siklus konsep stifin untuk menunjukkan eksistensinya dalam ruang lingkup Pendidikan. 
d. Feeling, diawali dengan memperbaiki moody, kemudian melibatkan orang lain adalah inti dalam proses belajarnya kemudian diakhiri evaluasi manakala terdapat penyakit regresi dan transkulpasi. nah, narasi pada bab sebelumnya menyatakan bahwa nilai peserta didik dengan kepribadian Feeling Introvert mampu mencapai nilai standar yang ditetapkan oleh satuan Pendidikan yaitu 70 dengan total nilai akhir diperoleh 85, Adapun nilai peserta didik dengan kepribadian Feeling Ekstrovert mampu mencapai nilai standar yang ditetapkan oleh satuan Pendidikan yaitu 70 dengan total nilai akhir diperoleh 90, sehingga dapat dikatakan ia telah berhasil menerapkan siklus konsep stifin untuk menunjukkan eksistensinya dalam ruang lingkup Pendidikan.

e. Insting, diawali dengan adaptibilitas kondisi yang damai, kemudian merangkum untuk menyimpulkan dan memperolah poin-poin penting dalam pembelajaran serta dievaluasi pula manakala terdapat penyakit belajar yaitu isolasi diri. Nah, dari narasi yang dideskripsikan pada Bab IV menunjukkan nilai peserta didik dengan kepribadian insting mampu mencapai nilai standar yang ditetapkan oleh satuan Pendidikan yaitu 70 dengan total nilai akhir diperoleh 85, sehingga dapat dikatakan ia telah berhasil menerapkan siklus konsep stifin untuk menunjukkan eksistensinya dalam ruang

\section{SARAN} lingkup Pendidikan.

Dalam proses memperoleh hasil belajar yang maksimal dibutuhkan pengorbanan, ilmu dan kolaborasi antara pihak guru, siswa maupun orangtua, sehingga dengan hadirnya konsep stifin ini, mampu menjadi ilmu peluang untuk menuntun anda menemukan "karpet merah". jika telah menemukan tapi tidak diasah tentu hasilnya pun tidak akan seperti yang diharapkan. cara ini adalah cara yang paling mudah, nyaman, dan sesuai dengan kodrat kita untuk meraih kehidupan sukses mulia, sehingga suatu saat kita tiada, bakat alamiah kita tidak terkubur bersama jasad kita melainkan ia tumbuh bersama orang-orang yang kita cintai lewat pengorbanan dan hasil belajar dan pengalaman.

\section{DAFTAR PUSTAKA}

Akademi Trainer. 2017. Worbook STIFIn Learning. Bekasi : Stifin Institute.

Asbari, Masduki. 2015. FOKUS SATU HEBAT, Jakarta : Dapur Buku.

Badaruzaman, Beni. 2014. Brain Genetic Potential, Bandung, Mizania : PT Mizan Pustaka.

Fadillah, Ahmad. 2016. Analisis Minat belajar dan Bakat Terhadap Hasil Belajar Matematika Siswa. Online. (fadiel_algebra @yahoo.co.id) Diakses 7 Januari 2020.

Poniman Farid. 2008. Kubik Leadership, Jakarta: PT Gramedia Pustaka Utama.

Hiday Miss. 2017. I KNOW YOU, Jakarta : STIFIn Institute.

Poniman, Farid. 2012. Konsep Pallugada( Apa lu mau gue ada), Jakarta : STIFIn Institute. Edisi 1.

Poniman, Farid. 2013. Konsep Pallugada ( Apa lu mau gue ada), Jakarta : STIFIn Institute. Edisi 2.

Poniman, Farid. 2014. Personaliti Genetik. Penemu STIFIn, Jakarta : Yayasan STIFIn.

Purnomo, Agung. 2017. Era Genetic, Bekasi : Yayasan Qurrotu A'yun.

Sugiono, 2009. metodologi Penelitian Naratif. Retrieved Online, Diakses 12 Januari 2020. From(https://www.google.com.metodepenelitiannaratifsugiono69i57j33.125287j0j\&ie=U $\underline{T F-8)}$

Susanto, A. 2013. Teori belajar dan pembelajaran di sekolah dasar. Jakarta : PT. Kharisma putra utama. 